\title{
The Power of Place: Tourism Development in Costa Rica
}

Article in Tourism Geographies · January 2012

DOI: 10.1080/14616688.2012.699090

\section{CITATIONS}

6

1 author:

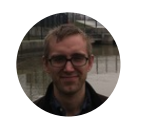

Eric Nost

University of Wisconsin-Madison

8 PUBLICATIONS 28 CITATIONS

SEE PROFILE

All content following this page was uploaded by Eric Nost on 26 February 2015. 
The Power of Place: Tourism Development in Costa Rica

Eric Nost

Tourism Geographies 15 (1), 88-106

http://www.tandfonline.com/doi/abs/10.1080/14616688.2012.699090\#.VO5kM_nF-b8

nost@wisc.edu

In this paper I question how representations of tourist destinations color and are colored by development. Presenting the results of ethnographic fieldwork conducted on the southern Carribbean coast of Costa Rica, I find that the authenticity of representations is important not for its veracity, but for the social work it performs. Authenticity is not merely socially constructed but expressive of social relations which value people and places. Tourist perceptions of the caribe sur as genuinely underdeveloped - gauged by an analysis of photos and guidebooks as well as surveys - produce an approach to resource use within the community that is limiting. Because the value of the place is its underdevelopment, development itself constrains the possibility of sustaining further growth. Ultimately, reading development via place can be a guide for critically appreciating contemporary patterns of tourism and sustainable development in the caribe sur and elsewhere.

Keywords: place, tourism, sustainable development, authenticity, Costa Rica

\section{Bar Brawls and Big Marinas: Tourism Development in Caribe Sur}

In this paper I question how representations of place color and are colored by development on the southern Carribbean coast of Costa Rica. The economic life of that region the caribe sur - depends upon tourism. To differing extents, the region's diverse population of English-speaking Afro-Caribbeans, nearly half of Costa Rica's indigenous population, HispanicCosta Ricans, and expatriate North Americans and Europeans participate in the tourism trade all make up .. Yet in spite of tourism, and the region's extensive history of community resource management and development (Frantz 2003; Gump 2001), Talamanca (which includes the coastal caribe sur as well as nearby mountainous areas) remains the most impoverished of the Costa Rica's 81 cantones. Recent events there have brought to the fore the connections between tourism, these development strategies, and representations of the region as a place.

In the early morning hours of April $19^{\text {th }}, 2008$, a resident of Cahuita - a small, relatively dispersed settlement of about 1,000 on the coast - was shot and killed at Coco's Bar, a popular hangout for tourists as well as locals. Although the reporting was relatively benign, the town has received critical attention in recent years for gruesome violence in a place that tourists and locals alike typically consider tranquilo. This type of negative press coverage is lamented by local business owners for scaring away potential tourists and damaging the local economy (Kelly 2004). 
Figure 1. The caribe sur. Source: Author.

A few days later at the University of Costa Rica (UCR), students draped a large banner that read "Long live Puerto Viejo - Without the Marina" over the campus's main library. The university newspaper, Semanario Universitario, had recently published a front-page story on a proposed marina complex to be sited in Puerto Viejo de Talamanca, a town about 15 kilometers south of Cahuita. The story articulated several of the potential ecological and social effects that the large-scale development might engender, such as damage to nearby coral reef systems and crime (Chacón 2008). In a similar report, a female U.S. tourist explained, "I'm a tourist and if this is constructed I won't come here anymore. I like the simplicity and naturalness of Puerto Viejo that would be lost with this" (Plaza and Carvajal 2008).

The shooting incident raises an appealing question. How does the image of a place motivate or daunt tourists and to what end for local economic development? The remark of the U.S. tourist, poses the reverse. It hints at a tension between development and the reasons travelers visit the region, suggesting that states of development inspire travel. She will only continue to travel to Puerto Viejo if the marina project, which would generate substantial revenue but ruin the town's "simplicity and naturalness", is scrapped. But what is the true character of the town? Is such an essential definition even available?

My answer is that in the caribe sur, depictions of place in brochures and text produce and sustain a dialectical communication between tourists and promoters about the place, in which its perceived authenticity emerges as the central selling point. Yet what travelers interpret as genuine is a lack of development - indeed, an historic underdevelopment. Such judgments of the place are central to conflicts over regional growth and management of natural resources. At the core of these contests, tourists, locals, and foreign residents all attempt to define the caribe sur. While tourism is heralded as a means to achieve development - and indeed, as the only road to development for poor peoples (UNWTO 2005 in Schellhorn 2010) - I argue thatthe negotiated results of such rhetorical maneuvering reveal a limited promise of sustainable development. Authenticity as Social Relation

Place, authenticity, and development each lay claim to their own literature within tourism studies. Place is conceived of as a locus that defines where tourism activities occur, as in a tourist destination (Crang 2006, Hernández-Lobato et al. 2006). Butbeyond geographical coordinates, the term bears notions of meaning. The representation of places inspires travel (Hernández- 
Lobato et al. 2006; Su 2010) as tourists decide where to visit after reading or hearing about a place (Young 1999; Urry 1990). But here crucial questions spring forth: how are these places imagined and by whom? Should places be understood more in terms of their performance (what is done in place) or their representation (what is portrayed of place)?

Places are best understood as constructed socially. They are the product of dynamic attempts at definition by various actors who operate and express themselves within capitalist, colonial, patriarchal, and other such structures. This meaning of place, moreover, is not static. It is continuously reworked through "agency, struggle, and resistance," (Tucker 2007: 142) be it by tourists (Tucker 2007; d'Hauteserre 2006), development interest groups (Schollmann et al.. 2001), or locals (Su and Teo 2008). Related, place is not simply "out there"; rather, it is made and remade by specific agents 2000).

However, within this constructionist view, the epistemology of place meaning is contested. Some consider place as knowable through its depiction in images, texts, and maps . Places can thus be read semiotically (Knudsen et al. 2007; Metro-Roland 2009). This perspective has the advantage of treating language and the "demarcat[ion of] social reality" (Schollmann et al. 2001) as powerful. However, a reliance upon extant imagery and text runs the risk of obscuring struggles at the heart of the creation of places, as images can be passively read (Crouch 2000). Instead, it is argued, place ought to be known by the ways people perform it (Crouch 2000, 2010; Minca 2007; Hanna et al. 2004). The meaning of place, then, is linked with what people do on the ground, in place, as part of a process.

The representation and performance of place are not mutually exclusive. In this study I approach place in a manner similar to Hanna et al. (2004) and Crouch (2010) in considering representation as a sort of performative work that is done by tourists, locals, and others - all those who weigh in on the matter and meaning of place. Images are not final products but contain a social and history a contemporaneous currency.

The performance of place may emphasize how individuals are disciplined and how that discipline is contested (Tucker 2007; Crouch 2000), but such a perspective misses out on important "powers" of place stemming from "wider economic and political relations of power" (Bianchi 2009: 490). The display of place is performed by multiple constituents in a matrix of power relations. Hanna and Del Casino, Jr. (2000) suggest that representations in maps and guides struggle continuously to "fix" identities by delineating what is appropriate for a given 
bounded space (see also Harvey 1990). The social production of space via this intertextual illustration is not essentializing. Rather, representations permit space for ambiguity, allowing for manifold disputes of meaning and it is this contestation which makes place identity in constant flux (Harvey 1990; Schollman et al. 2005; Hanna and Del Casino Jr. 2000; Cresswell 2000; Sundberg 2003; Lacy 2002; Su 2010; Davis 2005). Thus, a critique of representations can, when their creation and what work they perform is kept in mind, illustrate overlooked power in place. Authenticity

Authenticity has a contentious history as a concept in tourism studies (Wang 1999; Lau 2010; Reisinger and Steiner 2006). The questions of how authenticity is made to matter - if at all - and to what end have been dealt with diversely. Authenticity variously refers to verifiable cultural traits (MacCanell 1976), is negotiated (Cohen 1988), is socially constituted (DeLyser 1999; May 1996; West and Carrier 2006), or is simply unimportant (Reisinger and Steiner 2006).

Dydia DeLyser (1999) has written persuasively on authenticity. She suggests that authenticity is constructed at multiple scales; the validity of information about other cultures is filtered at an individual level, yet such filters are in many ways defined by broader trends in society. A tourist at a western U.S. ghost town may express their amusement at the anachronism of an authentic artifact, but such authenticity becomes "a vehicle through which the narratives of the mythic West, of progress, and American virtues, are made tangible and believable to visitors" (DeLyser 1999: 624). Authenticity is thus elicited in things, but is not a thing to be measured per se. Authenticity is a "vehicle," a means to an end. Notions of the authentic perform and the reason they can be valuable to researchers (cf. Wang 1999; Lau 2010; Reisingera and Steiner 2006) is because of the work they do to enroll people in social projects.

In this sense, authenticity is a social relation enacted between people. West and Carrier (2004: 485) approach this sort of conceptualization in building the salient claim that what ecotourists consider authentic is not derived from conservationists or any other informed individual or group, but "that it is the framework of Nature and the frontier" through which tourists judge authenticity. Importantly, this authenticity is inseparable from ecotourism, which they brand as a project of promoting markets in social goods. The convention that a particular nature is authentic enables an eco-friendly tourism to function as the neoliberal form of sustainable

development.

Davis (2005) elaborates on how landscapes are thusly transformed by conceptions of the 
world. Place representations discursively "legitimize certain uses and prohibits others" and in performing so produce the material landscapes of place (Davis 2005: 609). Authenticity as such a vision of place is a social relation, reproduced by tourists and locals. West and Carrier (2004) demonstrate this concept in Jamaican ecotourism. Discourse concerning authentic nature becomes, in dialectical fashion, actually existing material reality as tourists successfully make their claim to authorities to have fishing boats removed from areas around a beach. Authenticity becomes a social relation - valuing, ordering, and reorganizing people, places, and resources.

This authenticity cannot be engaged without considering the representation of place. Britton (1991) urged geographers to critique what he deemed "markers of tourism space" representations like maps, brochure images, guidebooks of travel areas. While Urry (1990) has been important in this regard others have added valuable contributions to the conversation (Edensor 1998; Del Casino and Hanna 2000; Davis 2005). Particularly, Catherine Lutz and Jane Collins's (1993) deconstruction of image meaning in the National Geographic magazine is useful. Lutz and Collins nullify the idea of the magazine as an unbiased scientific source by presenting how its printed images actually encode messages and value impositions about its subjects. The magazine projects cultures and places as harmoniously associated with nature and essentialqualities of human existence, yet this view contrasts with the dynamism of change which cultures and places readily experience. As in National Geographic photography, notions of authenticity are expressed through and embodied in displays of place. Moreover, such notions are more projections of social desires than realities (Wang 1999).

\section{Development}

If authenticity is indeed a social relation, how does it operate? How do ideas of place actually "find ground" and create social and material reality? In the Bikini Atoll, for instance, the might of U.S. military and media is a transformative power (Davis 2005). Yet the many means by which places are made visible are typically separated from questions of economic development.

As social relation, authenticity of place is inseparable from development - the interrelated social (e.g. income and well-being) and material (e.g. physical infrastructure like roads and resorts as well as environmental impact) aspects of economic growth. The uneven global development that sustainable development seeks to rectify is driven in part by forces of homogenization and differentiation in the capitalist economy (Smith 1990; Swyngedouw 1997). Capitalism tends towards equalizing the rate of profit across space and in place as it achieves 
greater economies of scale while it simultaneously seeks niches which yield comparatively high rates of profit. Consider that it is a commonplace that globalization standardizes places so that they become like everywhere else. However, Harvey (1990) has noted that in a globalized world, capital moves freely but locale remains fixed. In order to attract residents, businesses, or, in this case, visitors, places work to distinguish themselves from other, often homogenized, areas. Capital serves to augment the assembly of place and place-identity (Harvey 1993; O'Hare 1997; Kneafsey 1998; Sywngedouw 1997). As such, tourism may be "destroying" places, but at the same time it creating others.

Place, authenticity, and development can be analytically united. Sustainable development studies in particular tend to treat place as a mise-en-scène which enframes sets of peoples and resources whose interaction could be made more sustainable (Lu and Nepal 2009; Wearing et al. 2010; d'Hauteserre 2005) Thus, much of the work on tourism development focuses on how to manage destinations for growth (Young 1999; Landorf 2009). Related, such studies chart the trajectory of destinations' development (Saarinen and Kask 2008), as opposed to the processes which make such development contingent (d'Hauteserre 2005; Young 1999). In this vein, there is scant attention paid to explaining destination success or failure in terms of the way place identity is framed (cf. Hernandez-Lobato et al. 2006).

O'Hare (1996), however, posits a dialectical relation between place and tourism development on Australia's east coast. A "narrative of landscape" that historically depicted the area as relaxing informs development discourses. Decision-makers have codified the village's low-key atmosphere by enforcing building codes which restrict high rise projects. Yet the result of tourists' demand is not always a given; place ideas are often disputed. Saarinen (1998) emphasizes the power relationships between groups offering competing notions of development and place by describing how the transformation of a tourism region, in this case the Finnish Lapland, is dependent upon negotiated notions of development. Who gets to choose how local resources are managed? The answer regularly relies on a complex interaction of power. Bianchi (2003) proposes that, "tourism spaces, therefore, reflect the contest over the meaning and 'appropriate' use to which particular places should be devoted. " (Bianchi 2003, 27)

Place-meaning is therefore constituted by multiple parties within webs of power. Tourist promoters aim to ascribe an identity to place, as do locals, and authenticity is one key frame in which these identities are articulated. It is socially written at multiple layers from the individual 
(De Lyser 1999) to the state (Bianchi 2003) to the ideological (May 1996) and its performance is as a social relation amongst people and places. As such, authenticity is inextricable from the material matters

of development.

\section{Tourist Motivations for Visiting the Caribe Sur}

The style, scale, and materiality of tourism encountered on the Pacific coast of Costa Rica contrasts sharply with that of the Caribbean. Pacific tourism specializes in providing beach access and mass excursions and is heavily reliant on large-scale investment (national and foreign).Tourism in the caribe sur tends to center around intimate experiences with nature and culture and is undertaken with a smaller degree of investment and physical infrastructure (Anuario de Turismo 2006).

Tourism has replaced banana production as the mainstay of the regional economy there. Increased access to the region, the arrival of electricity in 1976, the failure of the cacao crop in the late 1970s and early 80s, and the establishment of Cahuita National Park in 1978 are both popularly and scholarly deemed additional contributors to the formation of the tourism industry in Cahuita (Leary 1996) and elsewhere in the region (Greencoast.com). In 1993, after the government proposed an entry fee increase at the national park, locals seized control of the park and started investing entry fees - now voluntary donations - in community projects (Frantz 2003). The period immediately following the takeover of park management, from the early to mid 1990s, is imagined by locals as the pinnacle of tourism in Cahuita. At some point in 1990s, main growth in the sector shifted to Puerto Viejo. The town lacks the immediate vicinity of a national park, but supplies a number of beaches which host excellent surfing conditions. In both places, tours to neighboring protected natural areas are popular.

\section{Methods}

Drawing upon original ethnographic study in the field in 2008, I assess text and image content analyses against what tourists themselves describe as motivations for visiting the caribe sur. A set of promoter (online and printed) and tourist photos was gathered for the image analysis. After an initial scan of the set for for major themes and reoccurring objects, coding questions were produced as a means of determining frequency in the depiction of: location (Puerto Viejo area, Manzanillo, Cahuita, anywhere else in Talamanca, or indiscernible), 
environment (town, jungle, beach, inside), people (how many, what kind, and activity), and the presence of wildlife, palm trees, hammocks, empty boats, or mountains (Djafarova and Andersen 2010). One-third of all images from each data set were randomly selected to craft a study sample (tourists, $n=30$; online promoters, $n=55$; print promoters, $n=26$ ), which was then coded.

Participatory observation can be an effective way of gaining access to tourists and understanding their experiences on their own terms (Cook 1997; Graburn 2002; Pereiro 2010). In Cahuita, I regularly volunteered at the local national park and beach. As part of this strategy, I used short surveys to seek out both tourists' and locals' perceptions of the area. 101 surveys were administered to visitors to Cahuita National Park along Playa Blanca and 38 visitors to Playa Cocles, located near Puerto Viejo. Interviewees were allowed to provide more than one answer. They were not asked to supply an overarching reply as to why they decided to visit or what they enjoyed the most. This approach entails methodological complications in that it is not entirely clear which motivations are primary, but provides richer qualitative data to work with and still generates basic quantitative results. Answers were distilled into a few main themes (Parfitt 1997). 49 short surveys were also collected from Cahuita residents. A fairly common tactic in tourism research (King et al. 1993; Chris Choi and Murray 2010), participants were asked about their favorite aspects of Cahuita, why tourists came to town, and the benefits and drawbacks of tourism

there.

Additionally, several longer semi-structured interviews were conducted with contacts in the community. Interviewees were owners of either restaurants or cabinas in Cahuita. Conversations were intended to get a sense of Cahuita's experience of tourism, particularly how tourism there has developed historically and its effects. Interviews with members and directors of charity, environmental, and developmental organizations in Talamanca were also undertaken to assess tourism in a broader, regional context. Images

Do promoters employ certain images as tools in selling the place and do tourists grasp and reproduce such rhetoric? For instance, while the Caribbean coast of Costa Rica is indeed populated by palm trees, the incidence of images depicting palm tree beaches in promotional material is likely exaggerated. This is interesting given that perhaps the most popular beach in all of Talamanca - Cahuita National Park - is lined with almond trees and relatively few palms. Promoters utilize the palm in a third of all photos, but it is featured significantly less in images 
grabbed by tourists. Palm trees are nearly 15 times more likely to appear in promoter pictures than in tourist pictures. The frequency of images displaying empty fishing boats is also exaggerated. Furthermore, there are only a handful of beaches in the region, yet beaches are heavily featured in both tourist and vendor images. However, online promoters are three times as apt to depict beach images as are tourists. Finally, there is an absence of crowds and other people from images of place. There are not as many people featured in tourist promotions as one would actually encounter in place regardless of the season.

The difference in imagery produced by promoters and tourists denotes a rhetoric that promoters employ and that tourists fail to reproduce. Promoters' imagery coalesces around a few elements like palm trees and empty boats, whereas tourists' imagery is less consistent. Standardized images become rhetorical devices through which promoters participate in the discourse of place. Tourists do not typically engage in and reproduce such rhetoric, as their aim is not to sell, but that is not to say that tourists do not internalize the promoter discourse. The meanings sustaining the rhetoric can still matter for tourists. Tim Edensor (1998, 13) explains that representations "are part of a technology of enframing sights which forms the epistemological apparatus through which tourists see and interpret difference." How do visitors to the caribe sur understand difference there? tourists' shots of a single building emphasize the West Indian architecture typical of the area. Broader takes of the town highlight greenery at the expense of the built environment. Related, there is an evident focus on depopulated spaces; very few images include people. Promoters stress that the caribe sur is a place with relatively few other tourists - a place where one could relax. Tourists agree; the only people within their photos are themselves. The use of palm tree beach imagery unites a larger ideal of the Caribbean as relaxing and natural in place at the scale of the Costa Rican caribe sur. The image of the palm has stereotypically signified a peaceful atmosphere and environment throughout the Caribbean (Daye 2005). Indeed, the gaze of both tourists and promoters is directed toward the (palm tree) beaches of the area. The vast majority of photos are taken either of the beach or on the beach, shunning the mountainous and indigenous interior. The caribe sur, at least in the tourist discourse, is distinctively a "sand and sun" place. 


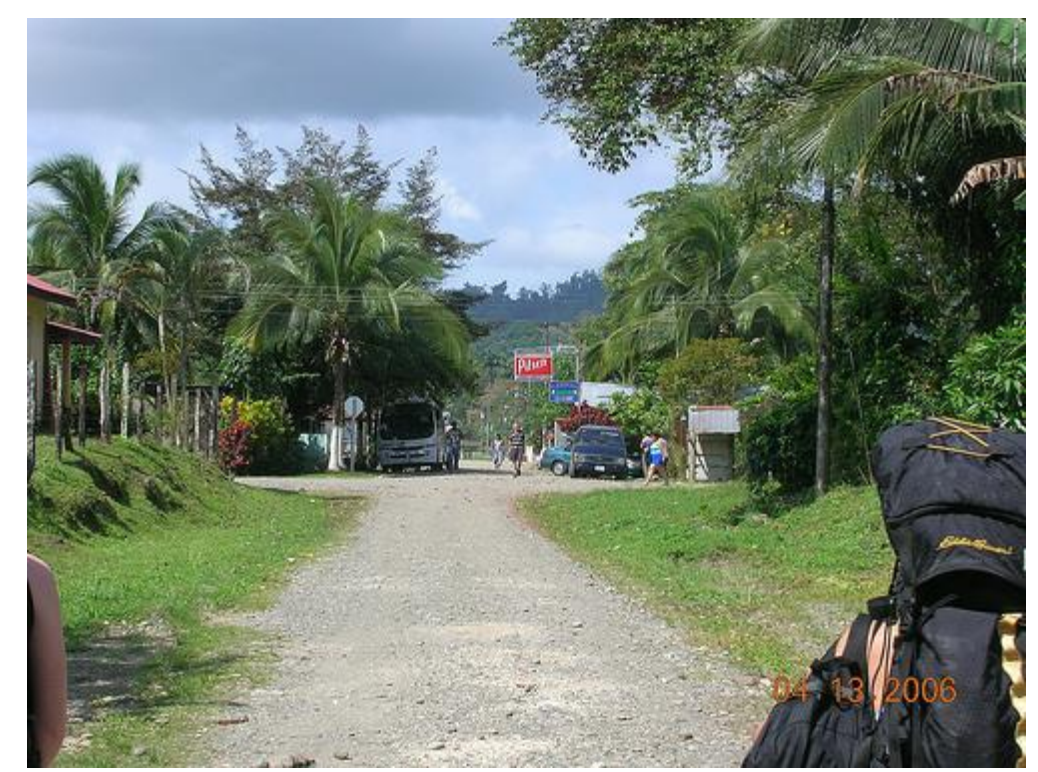

Figure 2. The main drag in Cahuita. Source: gusthebus20 - Flickr, 2006.

\section{Guidebooks}

Brochure images are not the only way travelers discover the area and are not the only way the caribe sur is made to matter for them. The frequent usage of guidebooks entails that information about the area is transmitted to would-be visitors through short, stylistic characterizations. In these texts, the caribe sur is again depicted as a place that is depopulated, natural, and relaxing.

I asked travelers to both Playa Blanca in Cahuita National Park (CNP) and to Playa Cocles, a ten minute walk from Puerto Viejo proper, how they first learned about either Cahuita or Puerto Viejo. The most common responses from visitors to the CNP were "Word of Mouth" $(\mathrm{n}=36,39 \%)$ or "Guidebooks" $(\mathrm{n}=34,37 \%)$. At Playa Cocles, "Word of Mouth" was overwhelmingly the most provided response. From the "Guidebooks" category, the one source that was specifically mentioned was Lonely Planet $(\mathrm{n}=16,17 \%)$. Lonely Planet describes Cahuita as having a "very laid-back vibe," "a decidedly Afro-Caribbean flavor" and as "breathtakingly beautiful" (Vorhees and Firestone 2006, 470). Descriptions of Cahuita encountered in other popular guidebooks like Fodor's all note an underwhelming physicality and lack of other tourists. Cahuita is "dusty," "laid-back," (Kelly 2004, 196) "offbeat," (Baker 1999, 383) comprised of "just two puddle-dotted, gravel-and-sand streets running parallel to the sea, intersected by a few cross-streets," (Kelly 2004, 196) and "a village [of] no more than two parallel dirt streets crossed by four rutted streets overgrown with grass, with ramshackle houses spread apart throughout" 
(Baker 1999, 383). Depictions of Puerto Viejo are analogous (Greenspan 2011), but reveal tensions between the town's economic growth and the tranquility that a historic lack of development has engendered. Puerto Viejo has a "laid-back attitude" and consists of "little more than one long paved road that follows the road," though it is also "touristy" (Voorhees and Firestone 2006, 480). "The development is low density," but a "boom in tourism has taken place in the last few years, "creating a "plethora" of tourist-related activities in town (Kelly 2004, 199). Figure 3. An empty boat in Puerto Viejo. Source: Greenspan, 2011. Surveys

What guidebooks intimate is that there exists a slight but substantial difference in attitudes toward Puerto Viejo and Cahuita. Importantly, the reasons images and guidebook text propose tourists travel to the area are reinforced by tourists' stated purposes. First, results from short surveys of tourists buttress previous findings (Gump 2001) that nature is a primary reason for visiting Cahuita. However, the data do not maintain the conclusion that nature is the primary reason for visiting Cahuita. More visitors responded, "I came here for the beach" (n=27, 27\%) than "I came here the flora, fauna, vegetation or other similar aspect of nature (other than the beach)" ( $n=20,20 \%)$ and just as many answered, "I heard it was a nice/beautiful place" (n=20, 20\%). Visitors to Cahuita National Park traveled to Cahuita not just because of its natural resources, beauty, or park, but also because it is a tranquil place that is "not over touristy" (n=19, 19\%). To visitors, Cahuita is "a relaxed town" and a "low-key place." Responses from visitors to Playa Cocles near Puerto Viejo differ from those at Cahuita National Park. Recommendations were tourists' principal motivation for traveling to Puerto Viejo ( $n=9,24 \%)$. Visitors remarked, "I heard it was nice from friends who had been here" or "it was recommended by two friends. They say you must absolutely go to Cahuita and Puerto Viejo.” Many visitors $(n=6,16 \%)$ answered that they traveled to Puerto Viejo randomly. Unlike Cahuita, natural surroundings are not a persuasive reason for visiting Puerto Viejo. Only a few respondents $(\mathrm{n}=2,5 \%)$ listed nature as a reason for traveling to the town. The data on tourist motives demonstrate a distinction between the two places, which observation and informal conversations sponsor. There are few responses from the Playa Cocles surveys that fit the "Nature" category, unlike Cahuita, where one-fifth of respondents replied that they had visited to encounter nature. Furthermore, though visitors to both places list the atmosphere as a purpose for visiting, many clarified that Puerto Viejo was more "congested" and 
had more people and nightlife than Cahuita, an argument Lonely Planet puts forth as well. Both Cahuita and Puerto Viejo are tranquil and natural places, but each to its own degree. Caribe Sur

as

Authentically Underdeveloped

The results of fieldwork narrate a common story. Images from promoters and text from guidebooks market the caribe sur as a relaxing, natural Caribbean getaway. At one level, tourists are merely seeking "sand and sun." Yet there are beaches elsewhere in the world, including many more on the Pacific coast (Costa Rica Tourism). Why do people elect to travel specifically to the caribe sur and to what end?

The correlation between tourist motivations and the representation of place ought to be viewed as a dialectical process, one that operates at different geographical scales. The manner in which the display of place is manufactured, framed, exported, and acted upon is a continuous give-and-take between tourists and promoters. Silver (1993) posits that it is local promoters who "contribute to how ideas of the Other are imagined and conceptualized within Western consciousness" (Silver 1993, 316). These promoters do indeed depict place and in many ways do so as they wish, without regard to tourists. However, those portraying place are not always local. Tourists regularly act on depictions provided by other travelers or media such as Lonely Planet. Moreover, visitors are rarely agenda-less and businesses have a real, fiscal incentive to appeal to what inspires travel. Thus, the rhetoric Talamancan promoters employ in images to gain customers is rooted in their understanding of tourists' desires. Empty boats and palm trees are entities encountered in the caribe sur that promoters feature because they can symbolize the experience promoters presume tourists will prefer. In this way, tourists' actions as bearers of place-ideas play a powerful role in fashioning general notions about - and as we will see, transforming destinations.

Even more incisive analyses of the dialectic are achievable. Tourist motives and placemeaning operate at various scales (Vaccaro and Beltran 2007). Generally, tourists consider Costa Rica an alternative to destinations elsewhere in the Caribbean like Cancún. Within Costa Rica, tourists deem the Caribbean coast as different from the mass tourism ventures on the Pacific. Yet visitors formulate one further distinction that highlights the fickle nature of tourist motivations. Between Puerto Viejo and Cahuita, they consider the latter to be less "touristy." In this model of decision-making, different travelers funnel into the places appropriate to their expectations of place. Thus, the traveler encountered in Cahuita and in Puerto Viejo may be regarded as the 
embodiment of a type of tourist that covets sand and sun, values local culture, seeks a relaxing atmosphere, and dislikes the presence of other foreigners.

This kind of tourist seeks the authentic in desiring the "pristine" and the "tranquil," traits which take form in space in Talamanca, not North America or Western Europe, or even the beaches of the Costa Rican Pacific. What is crucial to this authenticity is not its veracity, but what work it achieves. As May (1996: 321) notes, "at issue is not so much which image or meaning is correct, but it is a question of the material politics articulated by each vision." Importantly, then, it is the caribe sur's beaches, diversity, and historic underdevelopment which enable promoters in Cahuita and Puerto Viejo to represent an authenticity of place. That visitors invent distinctions between Cahuita and Puerto Viejo because of their ostensibly different development environments - when in fact the places are quite similar (Nost 2008) - stresses the value tourists discover in discerning genuine landscapes of development.

This claim is significant because notions of the caribe sur as an underdeveloped place are situated problematically against locals' desired development of the place. The work that authenticity performs is to develop social relations of a certain political economic kind; the value of the people and resources in this place is their underdevelopment. Yet these social relations do not go uncontested. The notion of the caribe sur as undeveloped belies struggles for development. The caribe sur is a "space stemming from a variety of social processes that are often occluded by its symbolic representations" (Bartling 2006: 394).

Recent project proposals underscore tensions between locals and foreigners. In 2008, an international firm presented the town with plans to construct a significantly-sized marina within the harbor of Puerto Viejo (Plaza and Caraval 2008). Though the plan has since then been withdrawn (Barquero 2008), the firm's intentions triggered an acute controversy. 


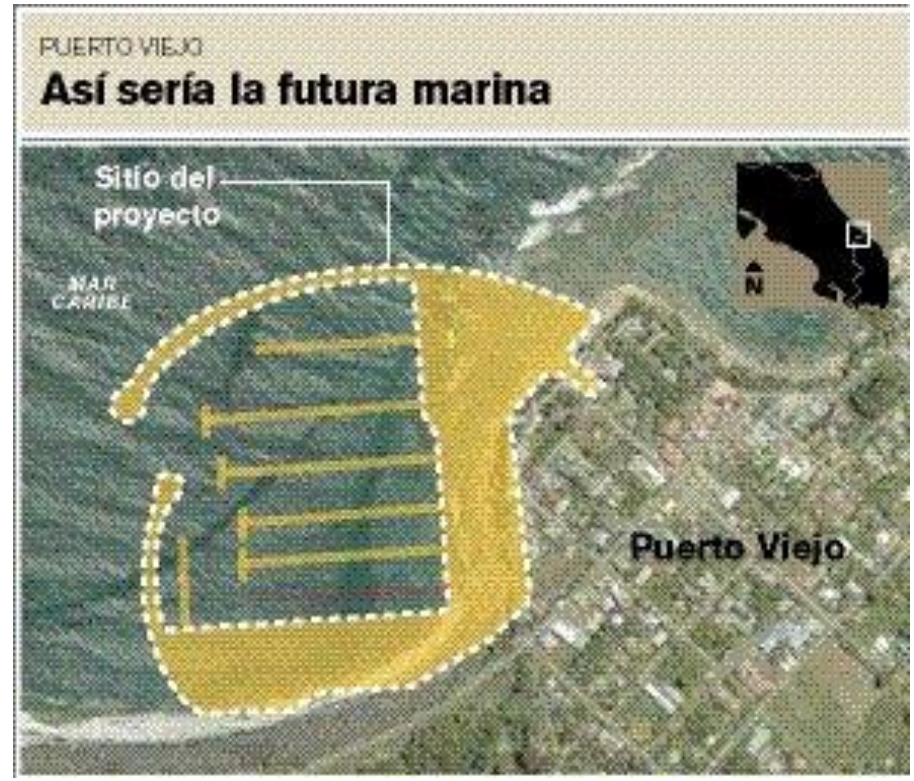

Figure 4. "The future marina" Source: Plaza y Carvajal, 2008.

Broadly, the project split both foreigners and locals. Ex-pats opposed the marina out of the fear that it would spoil the atmosphere and natural settings for which they had come to Puerto Viejo. Many actively participated in town hall councils on the issue. Individual tourists, always only an ephemeral presence in the area at any given time, likely did not weigh in very vocally (save the female tourist quoted earlier). But given the purposes for which tourists travel to the area they would have likely objected to the construction. Even other Costa Ricans, like the students who hung a banner at the UCR library, were concerned for the loss of the town's character. Some residents also adopted this stance, additionally rejecting the argument that such a plan would provide new jobs. However, other locals and foreigners either promoted the project or were indifferent. A few residents of Cahuita, for instance, noted in reference to not only the marina but tourism writ large, that it was Puerto Viejo's prerogative to manage its resources as it preferred. Other residents of Cahuita and Puerto Viejo saw the marina as a providential source of capital and employment. Furthermore, many ex-pats viewed adopting any (public) stance on the project as an unwieldy and unethical interference in others' affairs. These ex-pats believed that as foreigners they had no right to tell locals how to develop when many were so impoverished.

These debates over development strategies were at the same time integral to the creation of place-meaning. Individuals and groups, especially the coalition against the marina, drew upon notions of place to formulate their claim. In some sense, local ideas of place jibe well with the meaning tourists glean from the place. When asked, "what is your favorite part of Cahuita?" 
locals responded only with the beach $(n=21,39 \%)$, the tranquility $(n=14,26 \%)$, nature $(n=10$, $19 \%)$, and the people $(n=9,17 \%)$. These answers correlate strongly with tourists' motivations for travel and expectations of the place as measured through images, guidebooks and surveys. What is principal, however, is the way that these facets of place are manipulated. They are photographed, written about, or in any other way reduced and characterized so that the rhetoric and meaning that tourists receive is different than what locals experience in place. Images and guidebooks emphasize the beaches of the caribe sur, its tranquility, and the natural surroundings, but in a manner that adds a certain sense of the place as underdeveloped, a meaning that does not play out in the way locals perceive and discuss place. Indeed, in the debate over the marina, many of the meanings uncovered in the tourist discourse are subverted. A few videos made in opposition are emblematic. The author of one short video positions themself as outside of the community but aims to rally around the "danger" Puerto Viejo confronted (Salvemos Puerto Viejo 2008). Projected in front of images that could have been taken straight out of a brochure, the threat is made clear: "Goodbye to the surf, the tranquility, the local culture, the natural charm." The audience is encouraged to aid people who have "chosen to live at the rhythm of the Caribbean." The point here is straightforward: images can be put to different uses by different actors. The same authenticity is mobilized to sell tourism as it is to stop a marina. And yet a similar video from locals used typical imagery while making the argument that what it meant for residents to live in the caribe sur was not authenticity but a sense of pride in the community and the beneficial management of natural and cultural resources (¡No

a la

Marina

2008).

Thus, even though the creators of these film shorts and most foreigners both opposed the marina, they did so for deviating purposes. The tourist rhetoric's depiction of the caribe sur as authentic is situated problematically against the locals' portrayal because it characterizes the place as unpopulated and underdeveloped. The fact that such a tension exists between two parties critical of the project strengthens the proposition that meanings of place are manifold. Aporia of Tourism Development

The marina controversy was, on the surface, a referendum on development. In another sense it was centered on the meaning of place. It reveals how the portrayal of place in terms of authenticity creates social relations which are contested and reworked. The association between development and place meaning, then, is dialectical. The landscape enables tourism promoters to 
depict place as a function of its state of development (Davis 2005). In the context of the caribe sur, the resulting discourse fixes an identity of "authentically underdeveloped" to the space that is the caribe sur, setting the stage for how further development will take form. Will development be led by substantial foreign investment or with local capital, input, and ownership?

The answers are negotiated within a framework of power and privilege. The restriction of certain kinds and numbers of tourists aids the interests of foreigners who, like the female tourist from the U.S. quoted earlier, travel or move to the area explicitly for the relaxing vibe. When questioned, "why would you live there? There is nothing down there," one ex-pat responded, "personally I like it the way it is as it has kept the development down to a minimum and the 'Disney set' out and tends to cater to a more 'down to earth traveler.' I think the rumors and myths have served many of us who have chosen to live here very well" (Puerto Viejo Satellite). Foreigners deploy their influence in an endeavor to maintain the status quo.

Place is thus paramount to understanding development. Not because development takes place somewhere but because place encapsulates crucial social relations. A critical view of the discursive representation of place points to these relations. Notions of the caribe sur as authentic express a way of relating and ordering people, places, and resources (Crang 2006). Yet the goal is not to leave the analysis in the realm of representation, forgetting its "material" aspects (Bianchi 2009; Bartling 2006). Indeed, the illustration here of authenticity as social relation demonstrates how economic homogenization and differentiation find ground in place. Because the appropriate use value of this place has come to be its authentic underdevelopment, additional development erodes the possibility of further, sustainable growth.

But the tension between the need for further development, sustainable or not, and the tourist desire to visit an "undeveloped" space is real (see also Wainwright 2008). The traveler's desire for authentic difference does inherently constrict avenues for development; growth does not occur in a social vacuum. Even relatively small-scale ventures like indigenous village visits bring in wealth and the resulting infrastructural changes turn-off many kinds of travelers, for whom the meaning of place no longer corresponds with their expectations (Young 1999).

So, how to work through this aporia (Wainwright 2008)? There is no easy answer, but at the very least advocates of sustainable development must explore place as the intersection of social relations, instead of attempting to managerially revalue people and resources while ignoring or leaving in intact the very relations which may well undermine such revaluing. As 
Cresswell (2000: 11) asserts, "place is a way of seeing, knowing, and understanding the world." Comprehending development in the caribe sur via place is a guide for critically appreciating contemporary patterns of tourism and development in both the caribe sur and elsewhere.

\section{Bibliography}

¡No a la Marina de Puerto Viejo! (2008) YouTube - ¡No a la Marina de Puerto Viejo! http://www.youtube.com/watch?v=NjH54jiktTg (accessed 26 April 2009).

Baker, C.P. (1999) Costa Rica Handbook (Emeryville, CA.: Avalon Travel Publishing).

Bartling, H. (2006) Tourism as Everyday Life: An Inquiry into The Villages, Florida, Tourism 
Geographies, 8 (4): pp. 380-402.

Barquero S., M. (2008) Plan de marina en Puerto Viejo se archiva. La Nación, 8 August 2008.

Bianchi, R.V. (2003) Place and power in tourism development: tracing the complex articulations of community and locality, Revista de Turismo y Patrimonio Cultural, 1 (1): pp. 13-32.

Bianchi, R.V. (2009) The 'Critical Turn' in Tourism Studies: A Radical Critique, Tourism Geographies, 11 (4): pp. 484-504.

Britton, S. (1991) Tourism, capital, and place: towards a critical geography of tourism, Environment and Planning D: Society and Space, 9 (4): pp. 451.

Chacón, V. (2008) "Proyecto de marina enfrenta fuerte oposición" Semanario Universidad, 21 February 2008.

Chris Choi, H. and I. Murray. (2010) Resident attitudes toward sustainable community tourism, Journal of Sustainable Tourism, 18 (4): pp. 575-594.

Cohen, E. (1988) Authenticity and commoditization in tourism, Annals of Tourism Research, 15 (3): pp. 371-386.

Cook, I. (1997). Participant observation, in R. Flowerdew and D. Martin (Eds) Methods in Human Geography, pp. 127-150 (Longman).

Costa Rica Tourism. (2011) Costa Rican Beaches. http://www.tourism.co.cr/costa-ricabeaches/costa-rica-caribbean-beaches/index.html (accessed 12 March 2011).

Crang, M. (2006) Circulation and emplacement: the hollowed performance of tourism, in C. Minca \& T. Oakes (Eds) Travels in Paradox: Remapping Tourism, pp. 47-64 (Lanham, MD.: Rowman Littlefield)

Crouch, D. (2000) Places around us: embodied lay geographies in leisure and tourism, Leisure Studies, 19: pp. 63-76. 
Crouch, D. (2010) Flirting with Space: Thinking Landscape Relationally, Cultural Geographies, 14 (1): pp. 5-18.

Cresswell, T. (2004) Place: a short introduction (Oxford: Blackwell).

D'Hauteserre, A-M. (2005) Tourism, Development, and Sustainability in Monaco: Comparing Discourses and Practices, Tourism Geographies, 7 (3): pp. 290-312.

D'Hauteserre, A-M. (2006) A Response to 'Tracing the Commodity Chain of Global Tourism' by Dennis Judd, Tourism Geographies, 8 (4): pp. 337-342.

Davis, J.S. (2005) Representing Place: "Deserted Isles" and the Reproduction of Bikini Atoll, Annals of the Association of American Geographers, 95 (3): pp. 607-625.

Daye, M. (2005) Mediating Tourism: An analysis of the Caribbean holiday experience in the UK national press, in D. Crouch, R. Jackson, and F. Thompson (Eds) The Media and the Tourist Imagination, pp. 14-26 (Routledge).

Djafarova, E. and H-C Andersen. (2010) Visual Images of Metaphors in Tourism Advertising, in P. Burns, J-A Lester, and L. Bibbings (Eds) Tourism and Visual Culture Volume 2: Methods and Cases, pp.35-43 (CABI).

Del Casino Jr, V. and S. Hanna. (2000) Representations and identities in tourism map spaces, Progress in human geography, 24 (1): pp. 23-46.

DeLyser, D. (2003) Ramona memories: Fiction, tourist practices, and placing the past in Southern California, Annals of the Association of American Geographers, 93 (4) pp. 886-908.

DeLyser, D.(1999) Authenticity on the Ground: Engaging the Past in a California Ghost Town, Annals of the Association of American Geographers, 89 (4): pp. 602-632.

Edensor, T. (1998) Tourists at the Taj (Routledge).

Frantz, L. (2003) Co-management of Cahuita National Park: A Recent History, Thesis, Associated Colleges of the Midwest Tropical Field Research Program, San José, Costa Rica. 
Graburn, N.H.H. (2002) The Ethnographic Tourist, in G.M.S. Dann (Ed) The Tourist as a Metaphor of the Social World, pp. 19-40 (CABI).

GreenCoast.com. (2011) The Culture and History of the Puerto Viejo Area. http://www.greencoast.com/area-information/the-culture-history-of-the-puerto-viejo-area (accessed 12 March 2011).

Greenspan, E. (2011) Frommer's Top Destinations 2011 - Puerto Viejo, Costa Rica. http://www.frommers.com/micro/2010/top-destinations-2011/puerto-viejo-costa-rica.html\# (accessed 1 October 2011)

Gump, C. (2001) Cahuita and its National Park: The Green Image and the Green Tourist, Thesis, Asscoiated Colleges of the Midwest Tropical Field Research Program, San José Costa Rica.

Gusthebus20 - Flickr. (2006) Walking up to the Main Street, http://www.flickr.com/photos/28881105@N00/134288508 (accessed 21 June 2011).

Hanna, S.P., V. Del Casino, Jr., C. Selden, and B. Hite. (2004) Representation as work in 'America's most historic city', Social and Cultural Geography, 5 (3): pp. 459-481.

Harvey, D. (1990) The Condition of Postmodernity: An Enquiry into the Origins of Cultural Change (Cambridge, MA.: Blackwell).

Harvey, D. (1993) From space to place and back again: reflections on the condition of postmodernity, in J. Bird (Ed) Mapping the Futures, pp. 3-29 (Routledge).

Hernández-Lobato, L., M.M. Solis-Radilla, M.A. Moliner-Tena, and J. Sánchez-García. (2006) Tourism Destination Image, Satisfaction, and Loyalty: A Study in Ixtapa-Zihuatanejo, Mexico, Tourism Geographies, 8 (4): pp. 343-358.

King, B., A. Pizam, and A. Milman. (1993) Social impacts of tourism: Host perceptions, Annals $\begin{array}{lllll}\text { of Tourism } & \text { Research, } & 20 & \text { (4): } & \text { 650-665. }\end{array}$ 
Kneafsey, M. (1998) Tourism and place-identity: A case-study in rural Ireland, Irish geography, 31 (2): pp. 111-123.

Knudsen, D., A. Soper, and M. Metro-Roland. (2007) Commentary; Gazing, Performing, and Reading: A Landscape Approach to Understanding Meaning in Tourism Theory, Tourism Geographies, 9 (3): pp. 227-233.

Kelly, S. M. (2004) Fodor's Costa Rica (New York: Fodor's Travel Publications).

Lacy, J. (2002) Beyond Authenticity: The meanings and uses of cultural tourism, Tourist Studies, 2 (1): pp. 5-21.

Landorf, C. (2009) Managing for sustainable tourism: a review of six cultural World Heritage Sites, Journal of Sustainable Tourism, 17 (1): pp. 53-70.

Lau, R.W.K. (2010) Revisiting Authenticity: A social realist approach, Annals of Tourism Research 37 (2): pp. 478-498.

Leary, K. (1996) A Recent History of Cahuita, Thesis, Associated Colleges of the Midwest Tropical Field Research Program.

Lu, J. and S. Nepal. (2009) Sustainable tourism research: an analysis of papers published in the Journal of Sustainable Tourism, Journal of Sustainable Tourism, 17 (1): 5-16.

Lutz, C. and J. Collins. (1993) Reading National Geographic. University of Chicago.

MacCannell, D. 1976 The Tourist: A New Theory of the Leisure Class. New York: Schocken Books.

May, J. (1996) In search of authenticity off and on the beaten track. Environment and Planning Society and Space 14: 709-736. 
Metro-Roland, M. (2009) Interpreting Meaning: An application of Peircean Semiotics to Tourism. Tourism Geographies 11 (2): 270-279.

Minca, C. (2007) The tourist landscape paradox. Social and Cultural Geography 8 (3): 433-453.

Nost, E. (2008) "Tourism, Conservation, and Development in the District of Cahuita, Costa Rica." Thesis, Associated Colleges of the Midwest Tropical Field Research Program, San José Costa Rica.

O'Hare, D. (1996) Interpreting the cultural landscape for tourism development, Urban Design International, 2 (1): pp. 33-54.

Parfitt, J. (1997). Questionnaire design and sampling, in R. Flowerdew and D. Martin (Eds) Methods in Human Geography, pp. 76-109 (Longman).

Pereiro, X. (2010) Ethnographic Research on Cultural Tourism: an Anthropological View, in G. Richards and W. Munsters (Eds) Cultural Tourism Research Methods, pp. 173-187 (CABI).

Plaza, S. y Marvin Carvajal. (2008) Plan para construir marina crea controversia en Puerto Viejo, La Nacion, 5 April 2008.

Puerto Viejo Satellite. (2011) About Puerto Viejo, Costa Rica. http://puertoviejosatellite.com/about.php (accessed 12 March 2011).

Reisinger, Y. and C. Steiner. (2006) Reconceptualizing object authenitcity, Annals of Tourism Research, 33 (1): pp. 65-86.

Saarinen, J. (1998) Social Construction of Tourist Destinations: The Process of Transformation of the Saariselka Tourism Region in Finnish Lapland, in G. Ringer (Ed) Destinations: Cultural Landscapes of Tourism, pp. 154-173 (London: Routledge).

Saarinen, J. and T. Kask. (2008) Transforming Tourism Spaces in Changing Socio-Political Contexts: The Case of Parnu, Estonia, as a Tourist Destination, Tourism Geographies, 10 (4): 
pp. $452-473$.

Salvemos Puerto Viejo Costa Rica (2008) YouTube - Salvemos Puerto Viejo Costa Rica http://www.youtube.com/watch?v=PVEJFDzrilM (accessed 22 June 2011).

Schellhorn, M. (2010) Development for whom? Social justice and the business of ecotourism, Journal of Sustainable Tourism, 18 (1): pp. 115-135.

Schollmann, A., H.C. Perkins, and K. Moore. (2001) Rhetoric, claims making and conflict in tourist place promotion: the case of central Christchurch, New Zealand, Tourism Geographies, 3 (3): pp. 300-325.

Silver, I. (1993) Marketing authenticity in third world countries, Annals of Tourism Research, 20 (2): pp. 302-318.

Smith, N. (1990) Uneven Development: Nature, Capital, and the Production of Space (Blackwell).

Su, X. and P. Teo. (2008) Tourism Politics in Lijiang, China: An Analysis of State and Local Interactions in Tourism Development, Tourism Geographies, 10 (2): pp.150-168.

$\mathrm{Su}, \mathrm{X}$. (2010) The Imagination of Place and Tourism Consumption: A Case Study of Lijang Ancient Town, China, Tourism Geographies, 12 (3): pp. 412-434.

Sundberg, J. (2003) Strategies for Authenticity and Space in the Maya Biosphere Reserve, Peten, Guatemala, in K. Zimmerer and T. Bassett (Eds) Political ecology: an integrative approach to geography and environment-development studies, pp. 50-69 (Guilford).

Sywngedouw, E. (1997) Neither global nor local: "glocalization" and the politics of scale, in K. Cox (Ed) Spaces of Globalization, pp. 137-166 (Guilford).

Tucker, H. (2007) Performing a Young People's Package Tour of New Zealand: Negotiating Appropriate Performances of Place, Tourism Geographies, 9 (2): pp. 139-159. 
United Nations World Tourism Organization. (2005) Declaration on tourism and the millennium development goals, Sustainable Development of Tourism e-bulletin, p. 10. http://www.worldtourism.org/sustainable/ebulletin/dec2005eng.htm (accessed 12 March 2011).

Urry, J. (1990) The Tourist Gaze, (London: Sage Publications).

Vaccaro, I. and O. Beltran. (2007) Consuming Space, Nature, and Culture: Patrimonial Discussions in the Hyper-Modern Era, Tourism Geographies, 9 (3): pp. 254-274.

Visit Costa Rica.com. Anuario de Turismo 2006.

http://www.visitcostarica.com/ict/backoffice/treeDoc/files/Anuario\%20de\%20Turismo\%202006 \%20(VERSION\%20FINAL).pdf (accessed 12 March 2011).

Vorhees, M., and M. Firestone. (2006) Lonely Planet: Costa Rica (Lonely Planet).

Wainwright, J.D. (2008) Decolonizing Development: Colonial Power and the Maya (Malden, MA.: Blackwell).

Wang, N. (1999) Rethinking authenticity in tourism experience, Annals of Tourism Research, 26 (2): pp. 349-370.

Wearing, S., M. Wearing, and M. McDonald. (2010) Understanding local power and interactional processes in sustainable tourism: exploring village-tour operator relations on the Kokoda Track, Papua New Guinea, Journal of Sustainable Tourism, 18 (1): pp. 61-76.

West, P. and J. Carrier. (2004) Ecotourism and authenticity: getting away from it all?, Current Anthropology, 45 (4): pp. 483-498.

Young, M. (1999) The Social Construction of Tourist Places, Australian Geographer, 30 (3): pp. 373-389. 
